\title{
Guardianship of Women in Late Antique Egypt
}

\author{
Vasiliki Nikitopoulou \\ Faculty of Arts, Mansoura University, Egypt \\ vasilike2000@yahoo.gr
}

\begin{abstract}
In late antiquity, women could carry out various legal and business transactions not necessarily under the supervision or guardianship of men but in the presence of their husbands, or male children, or a relative who usually accompanied them in their transactions to the city authorities or laws. The Pater Familias never lost his power over his children, his family, and their possessions. Motherhood was one of the main ways in which women managed to escape custody and gain legal independence. But widows were always considered weak to defend their rights and property and often sought the help of the city's legal authorities. Undoubtedly, women even in late antiquity were much less privileged than men but active members as mothers and wives in the family.
\end{abstract}

Keywords: Guardianship of Woman, Patria Potestas, Emancipation, Curator, Roman Egypt, Byzantine Egypt.

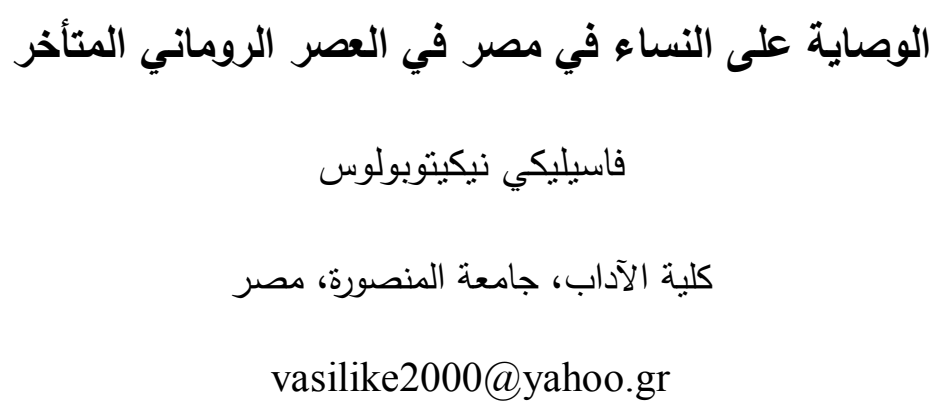

الملخص: كان بإمكان النساء في أواخر العصر الروماني المنأخر إجراء المعاملات القانونية والتجارية المختلفة ليس بالضرورة تحت إثراف أو وصاية أحد من الرجال ولكن بحضور أزواجهن، أو الأبناء الذكور ، أو أحد الأقارب الذكور الذي عادة ما يرافقهن في معاملاتهن لدى السلطات المدنية أو القانونية. وقد تمتع رب الأسرة بممارسة السلطة الأبوية على أطفاله وعائلته وممتلكاتهم، واعنبرت الأمومة إحدى الوسائل الرئيسية التي من خلالها تمكنت النساء من عدم الخضوع للوصاية، والحصول على الاستقلال القانوني، في حين أن الأرامل اعثُبرن في حاجة دائمة لمن يساندهن في الدفاع والحصول على حقوقهن وممتلكاتهن، وكثيرًا ما طلبن مساعدة السلطات القانونية في ذلك، وممَّا لا شك فيه أن النساء حتى في العصور القديمة المنأخرة كانت أقل قدرة من الرجال في الحصول على الحقوق والامنيازات، ولكنهن كُنَّ عضوات نشيطات في الأسرة كأمهات وزوجات. الكلمات الدالة: الوصاية على المرأة، سلطة الأب، التحرر، القَيم، مصر الرومانية، مصر البيزنطية. 


\section{Introduction:}

The institution of guardianship of women was mandatory and legally regulated in Greek and Roman society. In Egypt though, this legal reality was much more complex as pharaonic, Greek, and Roman legal practices intermingled ${ }^{1}$. The purpose of this paper is to shed light on this complicated reality of women in Egypt in Late Antiquities.

When Alexander the Great conquered Egypt, he brought with him Greek legal practices, which were to be practiced throughout the Hellenistic and Graeco-Roman period by Greek settlers. On the other hand, Egyptian women could continue to follow and practice their pharaonic legal traditions, which would allow them to perform legal and business activities independently. Of course, different legal practices dictated different destinies for the women and assigned different rights to their guardians.

Clearly, a rather complicated legal environment was developed in Graeco-Roman Egypt, by continuing to apply ancient Egyptian legal traditions at the same time as Hellenic legal practices ${ }^{2}$ as carried the restricting legal bias for women. ${ }^{3}$ And, finally, imperial laws, especially after the Constitutio Antoniana in 212 AD, when Roman citizenship was extended to the entire population of the Empire and thus, they had both the privilege and the obligation to follow the Roman legal order. ${ }^{4}$

\section{The Concept of Guardianship:}

Speaking of guardianship, the surviving papyri shed light on the tangled legal practices of guardianship, where habits and formalities interacted and contradicted. Needless to say that limits in history and life are blurred and, in our effort, to put this seemingly chaotic human action in order we need to focus carefully on the surviving evidence and the legal rules of late antiquity.

It does not need special justification to support those men and their power over children and women were the very basis of the sociopolitical structure of the Roman reality, whether we are researching Rome or the provinces. The guardianship of children and women, although seemingly similar, were quite different in reality. ${ }^{5}$ The guardian of the children was responsible for the upbringing, education and the protection of

\footnotetext{
${ }^{1}$ Uri Yiftach, Law in Ptolemaic and Roman Egypt, the Oxford Handbook of Ancient Greek Law, edit. by Edward M. Harris and Mirko Canevaro (Online Publication Date: Nov 2020), 28, 37-38. https://www.academia.edu/44471402/Law_in_Ptolemaic_and_Roman_Egypt_in_E_M_Harris_M_Canev aro_The Oxford_Handbook_of_Ancient_Greek_Law

${ }^{2}$ Aneta Skalec,"Men and women as neighbors in Ptolemaic and Roman Egypt (331 BC - 641 AD)": In (Wo)Men in Legal History. Centre d' Histoire Judiciaire (Poland: University of Warsaw, 2016), 257; cf. K. Vandorpe, \& S. Waebens, "Women and Gender in Roman Egypt: The Impact of Roman Rule in Tradition and Transformation: Egypt under Roman Rule", Proceedings of the International Conference, Hildesheim, Roemer- and Pelizaeus-Museum, 3-6 July 2008 (Leiden, Boston: Brill, 2010): 416 - 417.

${ }^{3}$ Skalec,"Men and women as neighbors", 257-258.

${ }^{4}$ Alan k., Bowman, Egypt after the Pharaohs: 332 B.C. - A.D. 642 from Alexander to the Arab Conquest (USA: University of California Press, 1989), 127 "Once obtained, the Roman citizenship carried very considerable legal and fiscal privileges, gave its holder the right and obligation to follow Roman legal practices in contacts, wills, marriages, rights over property and practices of guardianship of those not fully empowered to act in law (women, unless exempted, and men under twenty-five). It did not, however, extinguish the rights and obligations of the new Roman citizen to the local community from which he originated."

${ }^{5}$ R. Taubenschalg, The law of Greco-Roman Egypt in the light of the papyri, 332 B.C.-640 A.D. (Warszawa: Państwowe Wydawnictwo Naukowe,1955); Cf. P. Oxy 131466 (Oxyrhynchus; 245 CE), woman asked the prefect to appoint a guardian.
} 
children, while the guardianship of women was directly related to the representation of women in specific transactions. ${ }^{1}$

The concept of guardianship goes back to the Greek legal practice, which was practiced equitably by the Romans and the Graeco-Egyptians in Egypt. ${ }^{2}$

Before we focus on the concept of the guardianship of adult women, we should mention that girls, as boys, were under the domination of their father, ${ }^{3}$ under the legal institution of patria potestas. ${ }^{4}$

Under 'patria potestas', the 'pater familias' had lifelong rights over his family and the family property, ${ }^{5}$ and his power over his children ended by emancipation $(\chi \varepsilon 1 \rho \alpha \varphi \varepsilon ́ \tau \eta \sigma i \varsigma)^{6}$ or his death ${ }^{7}$. Until the time of Justinian (r. 527-565 AD), the law traditionally supported paternal authority over children born out of wedlock. Roman law always supported the father and gave him the right to expel his children in case of disrespect to their parents. ${ }^{8}$

The Roman patria potestas ended in ' for boys at 14, but the guardianship would remain in place until they reached the legal age of $25 .^{9}$ In the case of fatherless children a 'tutor' ('ं $\pi$ í $\tau$ -

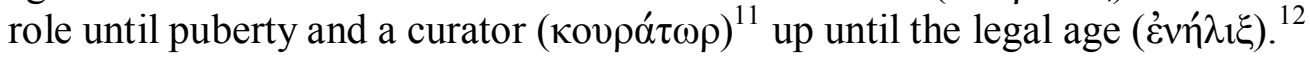

1 J. Grubbs, Women and the Law in the Roman Empire. A sourcebook on marriage, divorce and
widowhood (London and New York: Routledge, 2002), 18.
2 S. F. Johnson, The Oxford Handbook of Late Antiquity (Oxford, New York: Oxford University Press, 2012), 1348.

3 A. Arjava, The guardianship of women in Roman Egypt in Kramer, B. e.a. eds., Akten des 21. Internationalen Papyrologen Kongresses, Berlin 13-19.8.1995 (Stuttgart: Teubner, 1997), 25-27; A. Arjava, Women and Law in Late Antiquity (Oxford: Oxford University Press, 1996), 28 - 110; Cf. Grubbs, Women and the Law, 18-20.

${ }^{4}$ Johnson, The Oxford Handbook, 1348.

${ }^{5}$ Philip Esler, Modelling Early Christianity: Social-Scientific Studies of the New Testament in its context (London: Routledge, 1995), 210.

${ }^{6}$ Grubbs, Women and the Law, 106; cf. Arjava, Women and Law, 41, cf. P.Cair. Masp. 367353 (Aphrodito<Antinoopolis; $6^{\text {th }} \mathrm{CE}$ ).

7 M. Mirkovic, "Patria Rotestas or Murder in the Family", Annals FLB-Belgrade Law Review, Year LXIII, No 3, Anali Pravnog fakulteta u Beogradu, 63 (3) (2015): 5-17.

${ }^{8} \mathrm{Ph}$. Paschel, Iustiniani Institutiones, Liber primus, Tit 9, In potestate nostra sunt liberi nostri, quos ex iustis nuptiis procreaverimus. 1. Nuptiae autem sive matrimonium est viri et mulieris coniunctio, individuam consuetudinem vitae continens. 2. Ius autem potestatis, quod in liberos habemus, proprium est civium Romanorum: nulli enim alii sunt homines qui talem in liberos habeant potestatem qualem nos habemus.

${ }^{9}$ Grubbs, Women and the Law, 220; cf. Taubenschalg, The law of Greco-Roman Egypt, 178.

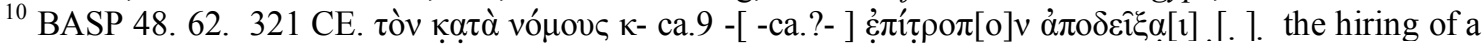
commissioner was legislated and mandatory for orphans in late antiquity.cf. S.P., Scott., The civil law, xiii (Cincinnati: Central Trust Co., 1932), the enactments of Justinian. The code, book v, T 29 With a view to providing for the welfare of natural children, We grant permission to their fathers to appoint guardians for them, to insure the administration of such property as they may have given or bequeathed them in any manner whatsoever; provided this is done within the limits prescribed by Our laws, and the said guardians are confirmed by a competent judge, and then administer the affairs of the guardianship.

${ }^{11}$ R. Mathisen, Law, Society, and Authority in Late Antiquity (Oxford: Oxford University Press, 2019). 228, cf. K. Cooper, and J. Wood, Social Control in Late Antiquity: the violence of small worlds (Cambridge: Cambridge University Press, 2021), 43.

12 J. Keenan, et al, Law and Legal Practice in Egypt from Alexander to the Arab Conquest. A Selection of Papyrological Sources in Translation, with Introductions and Commentary (Cambridge: Cambridge 
In a papyrus of the $4^{\text {th }}$ century next to Olympia is the curator where he helps her in legal matters according to the law. In this papyrus, next to Olympia, the curator helps her in legal matters according to the law “...vं $[\pi \grave{\varepsilon}] \rho$ 'O $\lambda[v] \mu \pi 1 \alpha v \hat{\eta} \varsigma[\theta v \gamma] \alpha \tau \rho$ ò $\varsigma$

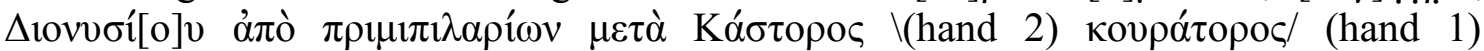

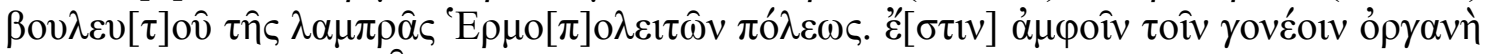

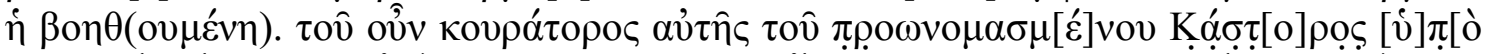

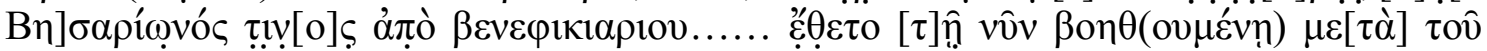

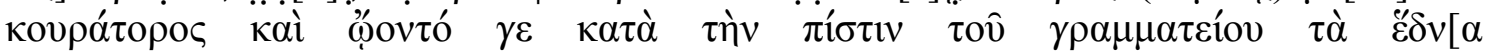

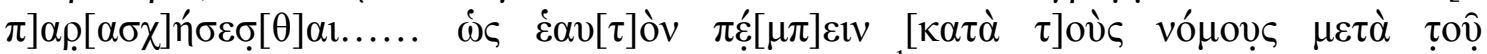

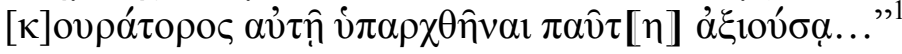

In another papyrus of the $6^{\text {th }}$ century, the state could be appointed the curator by the

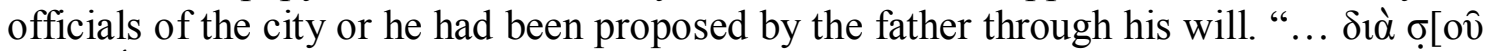

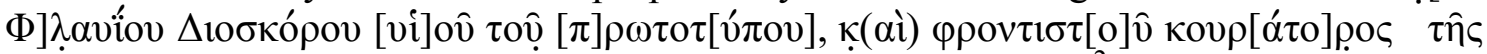

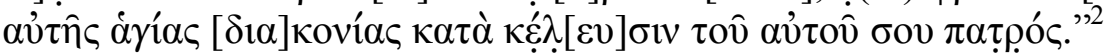

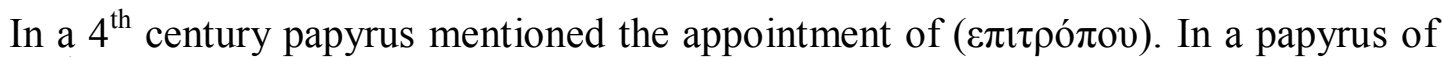
the $3^{\text {rd }}$ century, we see a petition illustrates the downside of family relationship, an orphan claims that her two uncles had conspired to defraud her of her maternal inheritance. It was common for guardians to injustice the wards. There are many cases in the documents where the guardians hurt the wards and their property. "... $\pi \alpha \rho \dot{\alpha}$

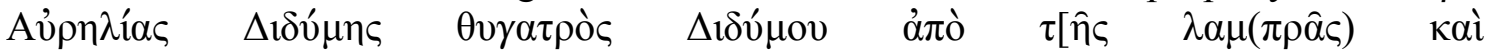

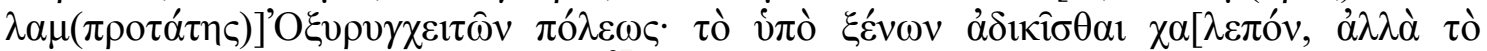

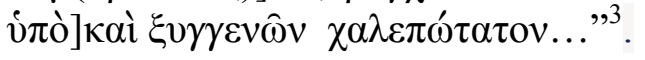

The guardianship was not only a legal obligation, but also a moral duty towards their wards and their social and financial well-being. ${ }^{4}$ When minor women reached puberty, they shifted to 'tutela mulierum', which was a complicated institution but less controlling than 'tutela impuberum', because tutors did not have absolute control over their ward and their property. ${ }^{5}$

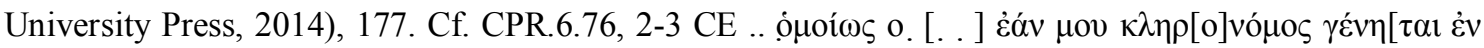
غ̇vvó $\mu \omega \dot{\eta} \lambda \iota \kappa i ́ \alpha . .$.

${ }^{1}$ Chrest. Mitt. 300 (Hermoupolis Magna; IV CE).

${ }^{2}$ P. Cair. Masp. 167096 (Aphrodito, Aphroditopolis 573 CE).

${ }^{3}$ P. Oxy. 34. 2713 (Oxyrhynchus; 297 CE).

${ }^{4}$ V. Vuolanto, Women and the Property of Fatherless Children in the Roman Empire. In Women, Wealth and Power in the Roman Empire., Setala, P. et. al. Vol. 25. Rome: Acta Instituti Romani Finlandiae. (2002), 205, cf. Papyrological data reveal quarrels between guardians and wards P. Abin 56, P.Cair. Isid. 62, BGU I 98, cf. Rowlandon Jane, and R. Bagnall, Women and society in Greek and Roman Egypt: a sourcebook (Cambridge, U.K.: Cambridge University Press, 2009), 94-95, cf. P. Oxy. 34.2713

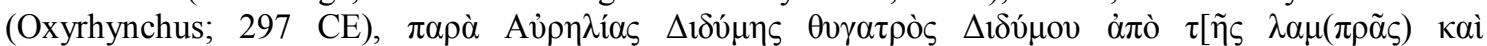

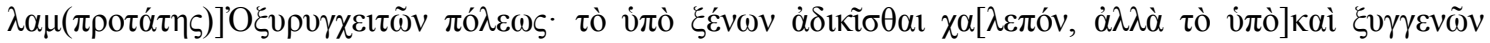
$\chi \alpha \lambda \varepsilon \pi \omega ́ \tau \alpha \tau o v$. This petition illustrates the downside of family relationship; an orphan claims that her two uncles had conspired to defraud her of her maternal inheritance. It was common for guardians to injustice the wards. There are many cases in documents where the guardians hurt the wards and their property.

${ }^{5}$ L. Caldwell, The Female Transition to Adulthood in the Early Roman Empire (Published PhD diss., University of Michigan, 2004), 91. Cf. Scott, The civil law T 28, 2" In Justinian's law we read that if the father lives after his children come of legal age he could supervise their property if it was necessary. Although the guardian who was legally appointed for you by your father's will was living at the time when you became his heir, still, as another was also legally appointed for you by a codicil, both of-them will be your guardians under the will of the testator; unless your father revoked the testamentary appointment by designating the other mentioned in the codicil, for then the latter alone will be your guardian". 
The guardianship of women, either as minors or as adults, was present in Roman Egypt; however it is evident that the status of women changed significantly over the centuries.

In Egypt, according to the local law, 'patria potestas' ended for young women with their marriage or by $\dot{\alpha} \pi$ oкń $\rho v \xi 1 \varsigma,{ }^{1}$, while for Roman citizens patria potestas' continued up until the father's death or by emancipation $(\chi \varepsilon 1 \rho \alpha \varphi \varepsilon ́ t \eta \sigma \eta) .{ }^{2}$ In other words, Roman women were expected to have a guardian to perform legal activities ${ }^{3}$ as it will be mentioned.

In a $2^{\text {nd }}$ century papyrus, we see the father denouncing his children and appointing as

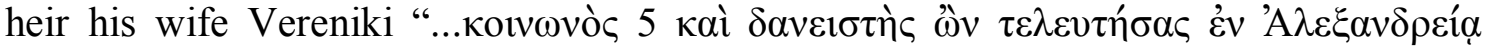

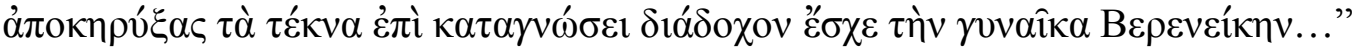

In a $2^{\text {nd }}$ century, we see the father having the power to divorce his daughter " ... $\varepsilon \dot{\varepsilon} \varphi$ ' ov

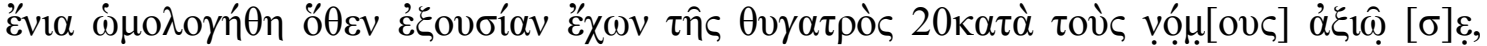

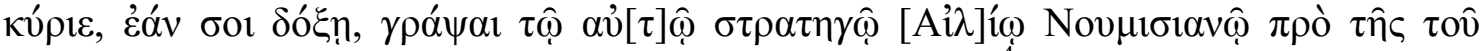

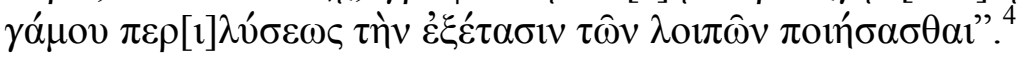

In a document from the $6^{\text {th }}$ century, we can discern the power and autonomy that a father had on his property. The father disinherited his three children from their paternal property and express the worse insults and curses against them ".... ớ

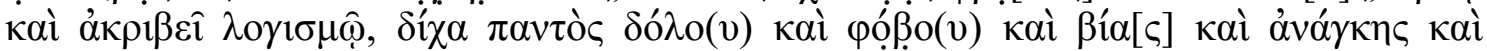

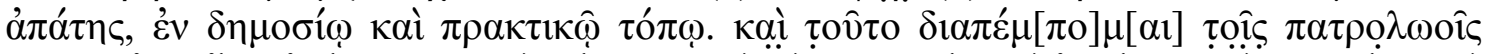

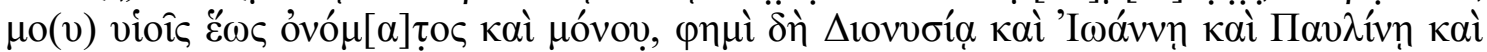

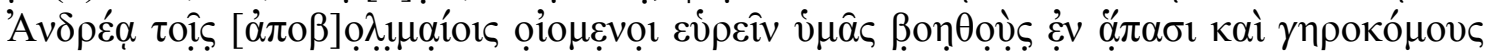

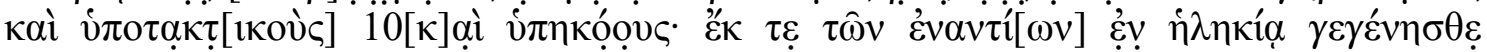

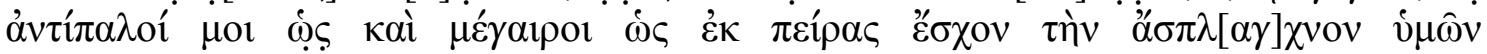

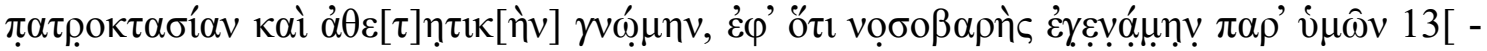

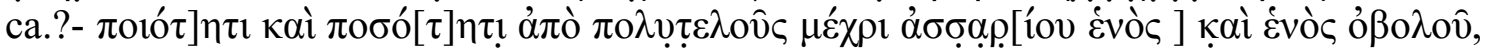

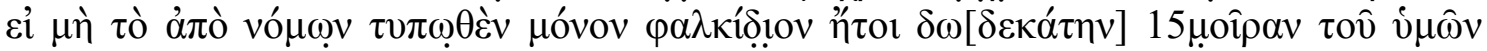

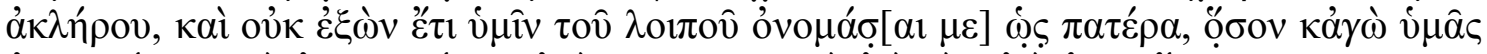

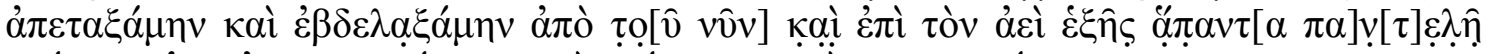

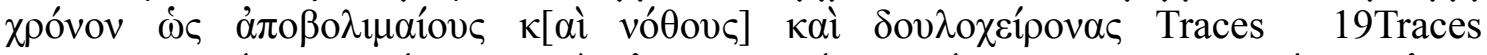

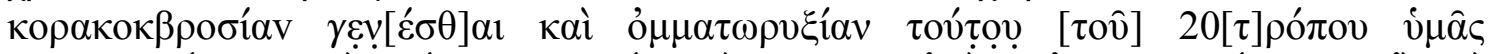

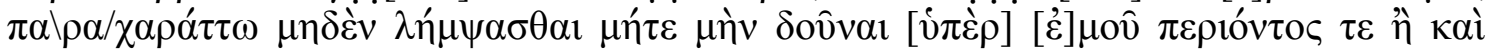

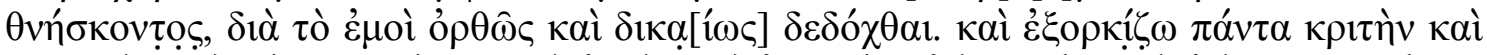

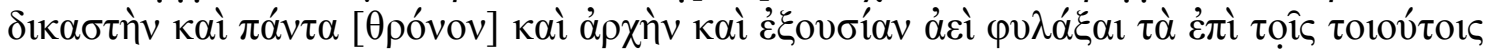

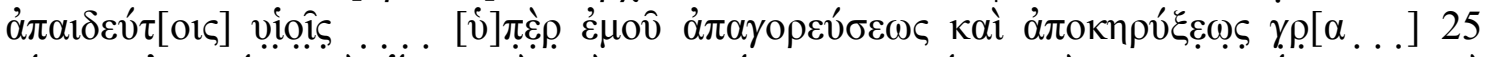

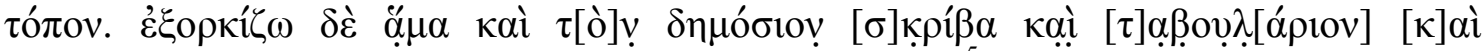

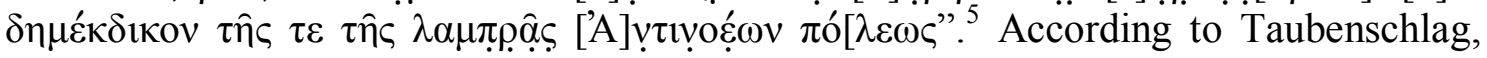

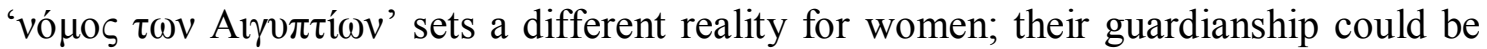
performed by their parents only if the woman was born in an 'ó $\gamma \rho \alpha \varphi \circ \varsigma \gamma \alpha{ }^{\prime} \mu \varsigma^{\prime}$ ' and she

\footnotetext{
${ }^{1}$ R. Taubenschlag, The law of Greco-Roman Egypt in the light of the papyri, 332 B.C. - 640 AD. (Warszawa: Panstwowe Wydawnictwo Naukowe, 1955),137

${ }^{2}$ Taubenschlag, The law of Greco-Roman Egypt 137,143; cf. Scott, The civil law, T17, 5, the father of an emancipated daughter cannot, at will, authorize her divorce.

${ }^{3}$ P. Oxy. 22. 2342 (Oxyrhynchus; 102 CE); J. Gardner, Women in Roman Law \& Society (Bloominghton and Indianapolis: Indiana University Press, 1986), 5.

${ }^{4}$ P. Mil. Vogl. 4229 (Tebtynis; 140 CE).

${ }^{5}$ P. Cair. Masp. 3. 67353 (Aphrodito<Antinoopolis; 6th CE).
} 


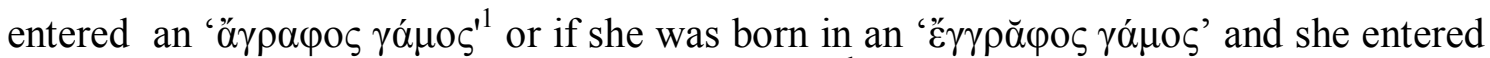

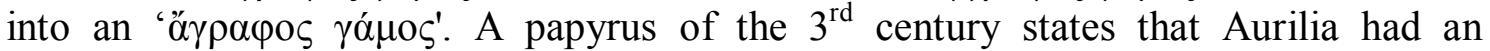

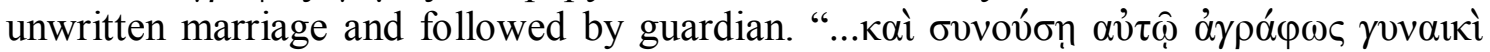

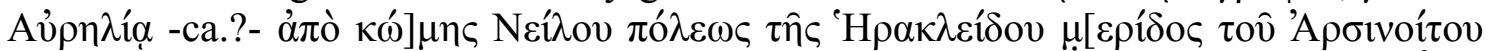

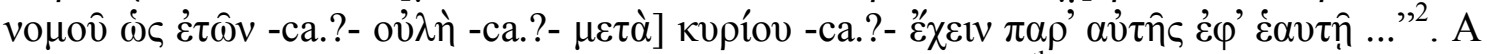
reality followed by the Romans as well, at least up to the $4^{\text {th }}$ century, where evidence suggests so. ${ }^{3}$ In the imperial age, the Romans married 'sine manu', meaning that a married woman remained under the legal power of her father rather than her husband. ${ }^{5}$

In the $6^{\text {th }}$ century, the father is asking for dissolution of his daughter's marriage because he heard about the gloom disliking things. For example, the father Ioannes had

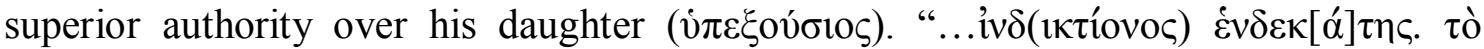

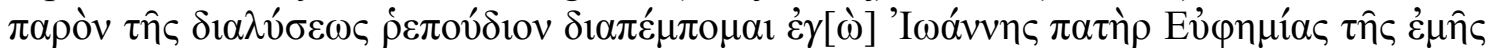

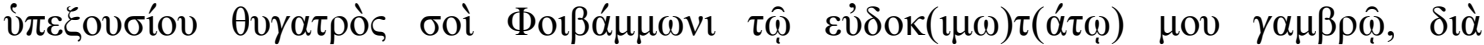

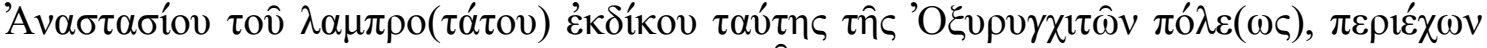

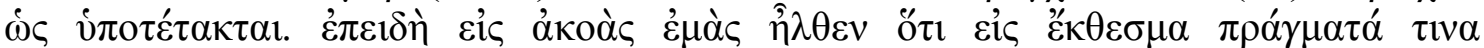

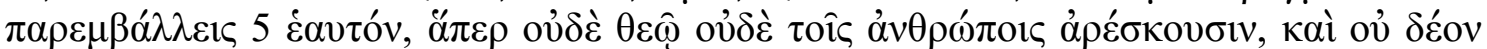

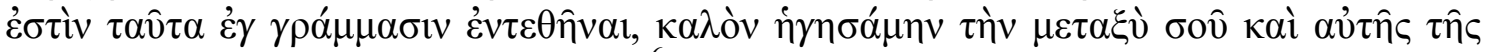

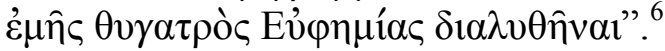

Among other obligations, the local patria potestas included the selection of a husband for the daughter. However, according to the same source, ${ }^{7}$ exceptions were observed between the $1^{\text {st }}$ and $6^{\text {th }}$ centuries, where women would choose their husbands independently. ${ }^{8}$ Notwithstanding exceptions, the guardianship of women was evidently present in Hellenistic and Roman Egypt and the guardians were appointed either as statutory or testamentary, or if the women requested so from the authorities. ${ }^{9}$ Roman women would apply to the prefect for a guardian and Greek women to the Strategos. ${ }^{10}$ In documents from Egypt before the Edict of Caracalla (211-217 AD), Roman and nonRoman women requested the appointment of a guardian, ${ }^{11}$ known as a datio tutoris.

\footnotetext{
${ }^{1}$ P.Hamb.3.220 (Arsinoiton Polis, Krokodilopolis, Ptolemais Euergetis?; 223 CE).

2 P.Mil.Vogl. IV. 229 (Tebtynis; 140 CE).

${ }^{3}$ Taubenschlag, The law of Greco-Roman Egypt, 141.

${ }^{4}$ Vuolanto, Women and property, 207. ...Cum manu marriage put the woman under the legal authority of the husband while the Sine manu marriage meant the woman remained under the legal authority of her father...

${ }^{5}$ P. Hamb 3220 (Arsinoiton Polis, Krokodilopolis, Ptolemais Euergetis?; 223 CE). cf. Chr. Mitt 300

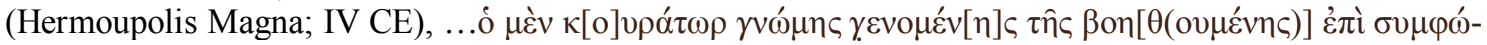

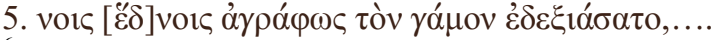

${ }^{6}$ P.Oxy.1 129 (Oxyrhynchus; 501-600 CE).

${ }^{7}$ Taubenschlag, The law of Greco-Roman Egypt, 125.

${ }^{8}$ G. Clark, Women in late antiquity: pagan and Christian life-styles (Oxford: Oxford University Press, 2008), 15.

${ }^{9}$ Taubenschlag, The law of Greco-Roman Egypt, 172.

10 I. Mueller, "Lower-class widows and their social relationships: A comparative study of Roman tombstone inscriptions and papyri from Roman Egypt". In Le rôle et le statut de la femme en Égypte hellénistique, romaine et Byzantine, Studia Hellenistica 37, ed. Henri Melaerts and Leon Mooren (2002),

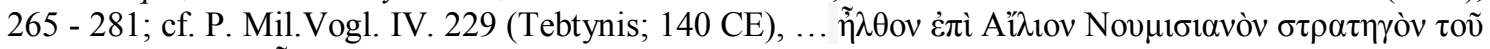

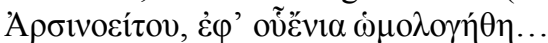

${ }^{11}$ Grubbs, Women and the Law "It is in Greek, and from a woman who is not a Roman citizen and who needs a kyrios in order to borrow money. If a woman in Egypt who was not a Roman citizen did not have a kyrios (perhaps because she was a widow without grown male children) and wanted to transact a matter requiring a kyrios' approval, she would request a kyrios for that one transaction. Through the body of the
} 
In a papyrus of the $3^{\text {rd }}$ century, Aurelia applied to praefect to be appointed guardian Valerio Firmo praef(ecto) Aeg(ypti) ab Aurelia Arsinoe. rogo, domine, [des mihi

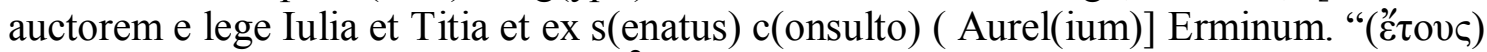

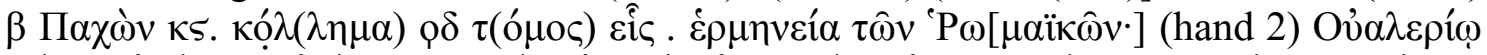

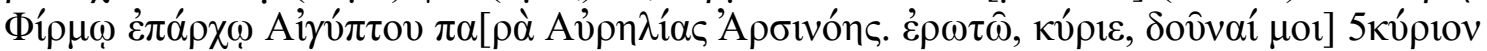

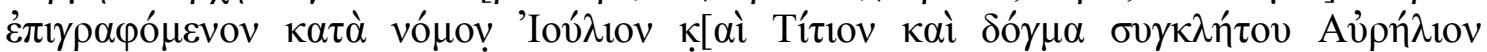

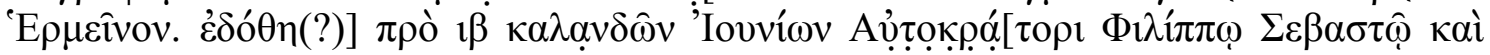

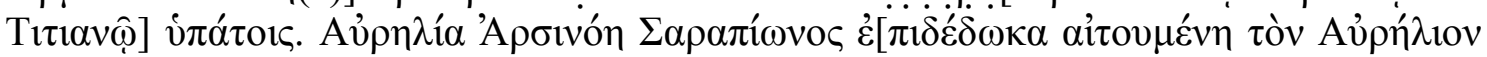

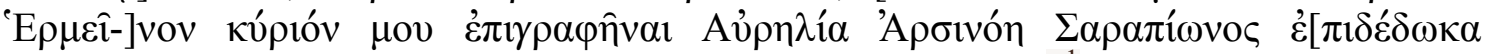

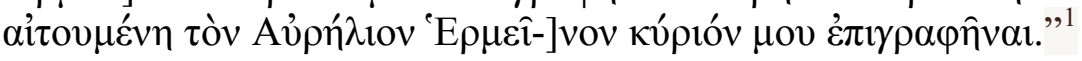

According to Roman law, the guardian of an adult woman was needed to perform certain legal and business transactions; sell imperial land, oxen and slaves as well as to make a will, give a dowry, emancipate a slave, or to assume an obligation. ${ }^{2}$

On the other hand, ancient Egyptian practice suggested women could act freely without a guardian, up until the $1^{\text {st }}$ century $\mathrm{AD}$ when the use of Demotic and subsequently the use of Egyptian legal tradition ceased. ${ }^{3}$ While the Greek law, in the provinces of the Empire, provisioned a guardian's consent only necessary in selling land or houses but the guardian in the provinces had wider scope as the local traditions steadily and increasingly became affected by Greek legal practice. ${ }^{4}$ According to Ada Nifosi who researched Demotic and Greek contracts from Egypt, we understand that Roman and Greek guardianships were comparable. ${ }^{5}$

In Egypt, in the $1^{\text {st }}$ and $2^{\text {nd }}$ centuries, the guardianship of women was legally present and Roman, Greek, and Egyptian legal principles would be followed. ${ }^{6}$ Towards the end of the $3^{\text {rd }}$ century $\mathrm{AD}$, the legal freedom of Egyptian women disappeared, as did the official use of the Demotic, which meant the use of Egyptian legal practice and tradition was dejected by the Roman administration. ${ }^{7}$

The legal reality reflected the social reality; where popular ideas depicted women as light minded and ignorant of legal issues and procedures. Gaius confirms that "...for the ancients required women, even if they were of full age, to remain under guardianship on account of the levity of their disposition". 8

petition was written by someone else (probably a professional scribe), Tabesammon, who explicitly says that she is literate, signed it herself. Petitions for assignment of a kyrios were sent to a regional official, the strategos of the nome (district) where the woman lived, or his deputy, the "royal scribe" (basilikos grammateus). In the absence of both these officials, Tabesammon has addressed her request to a municipal official, the exegetes," 35; cf. P.Oxy. 1.56 (Oxyrhynchus; 211 C.E).

${ }^{1}$ P.Oxy. XII.1466 (Oxyrhynchus; 245 C.E).

2 Arjava, The guardianship of women, 28.

3 A. Nifosi, Becoming a woman and mother in Greco-Roman Egypt: women's bodies, society and domestic space (London, New York: Rutledge, Taylor et Francis Group, 2019), 8.

${ }^{4}$ Arjava, The guardianship of women, $27-28$.

${ }^{5}$ Nifosi, Becoming a woman and mother, 148.

${ }^{6}$ Arjava, The guardianship of women, 4-5.

${ }^{7}$ Nifosi, Becoming a woman and mother, 235.

${ }^{8}$ Gaius, Institutes I.144: Parents are permitted to appoint testamentary guardians for their children who are subject to their authority, who are under the age of puberty, and of the male sex; and for those of the female sex, no matter what their age may be, and even if they are married; for the ancients required women, even if they were of full age, to remain under guardianship on account of the levity of their disposition. 
The multi-legal system, which was observed in Egypt had two branches: Imperial law and local law, while the peregrine law ${ }^{1}$ itself consisted of two different legal practices; Egyptian traditional legal practice and Greek law.

The very essence of guardianship of children, especially in Late Antiquity was "to protect the patrimony until the heir came of age," 2 and it would support the same for women who, "given their natural weakness", 3 needed a guardian to protect their "honor" "honor" and the property from alienation. In the $4^{\text {th }}$ century, we see widows protesting

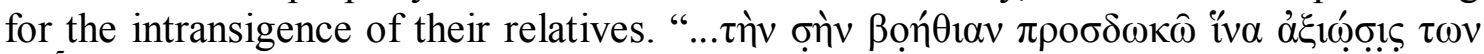

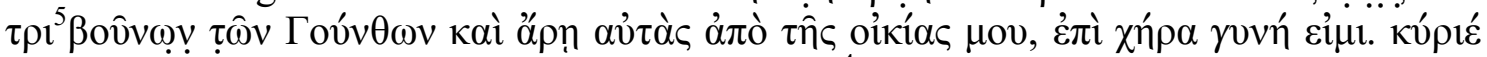
ov...." In this papyrus, the relatives of the widow. ${ }^{4}$

In another papyrus, Launus, the widow demands to receive her income from her

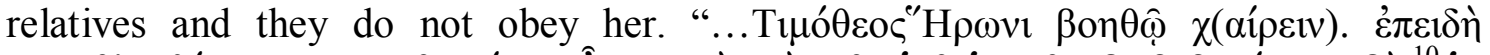

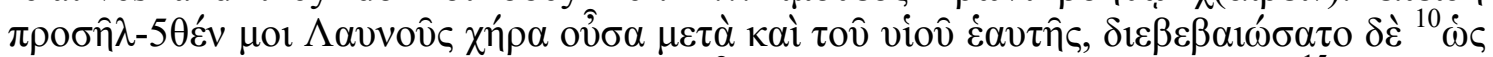

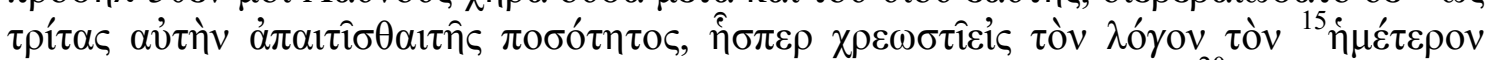

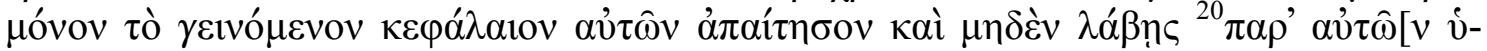
] $\varepsilon_{\varepsilon} \rho \pi \lambda \varepsilon o v . "$ In this document, the weakness of a widow who asked the authorities to protect her from the unjust behavior of her relatives is obvious.

This legal situation gradually changed, and the guardianship of women seems to have reduced institutional power ${ }^{5}$ and after $230 \mathrm{AD}$ guardians become rare. ${ }^{6}$ While Imperial law put women under a close relative who would serve as a guardian, there was also wide use of the Augustan Ius Trium / Quatrum Liberorum till Late Antiquity ("right of three children" / or "right of four children" for non-Romanized women), which would

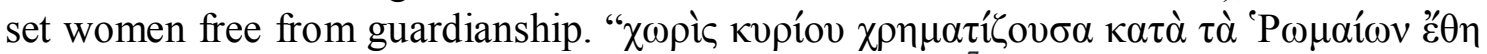

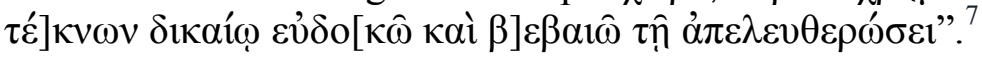

Egyptian papyri provide evidence of women who act without a kyrios (guardian) on the grounds of the ius trium liberorum, which gave women legal independence ${ }^{8}$. The Ius Ius Liberorum cited women until 389 CE. ${ }^{9}$

Sheridan in her analysis shows that mostly women from the Bouleutic class would take advantage of the ius trium liberorum, as the legal process to obtain it and the

\footnotetext{
${ }^{1}$ J. L. Alonso, "The status of peregrine law in Egypt", Journal of Juristic Papyrology 43 (2013): 351-404 (2015) 'customary law' and legal pluralism in the Roman Empire, papyrology AD 2013 27th International Congress of Papyrology, 351-404, 353-355. The family and the inheritance law in Roman Egypt was according the Peregrine law, Cf. Yiftach, Law in Ptolemaic and Roman Egypt, 10, 58. The Ptolemaic and Roman states recognized the gaps in their own legislative activity and therefore recognized alternative sources of law. In the same way, the authors of the contracts were ready to recognize the gaps in their contracts, which had to be regulated by other means, namely law and custom that was the peregrine law.

R. Saller, Patriarchy, property and death in the Roman Family (Cambridge: Cambridge University Press, 2009), 156.

${ }^{3}$ P. Herm. 17, 4 (375 - 399?; CE).

${ }^{4}$ BGU 2412 (?; $\left.{ }^{\text {th }} \mathrm{CE}\right)$.

${ }^{5}$ Arjava, The guardianship of women, 28.

${ }^{6}$ Keenan, Law and Legal Practice 177.

7 BGU 196 (Arsinoite; 250-300 CE), cf. BGU 3863 (Arsinoite; 201-300 CE), cf. CPR 714 (Hermoupolis Magna; 305 CE), P. Aberd 180 (?; 305-325 CE).

${ }^{8}$ Grubbs, Women and the Law, 36.

${ }^{9}$ K. Harper, Marriage and Family in late antiquity in S. F. Johnson, Oxford Handbook of Late Antiquity (Oxford, New York: Oxford University Press, 2012), (prepublication copy).10
} 
associated fees could be quite a financial burden. In addition, women from the Bouleutic class, as well as wealthy women of any class, would have reasons to chase their legal freedom. ${ }^{1}$

The law, also, did not set any prerequisites (e.g. literacy), although we have evidence where a woman "adds...that she is also literate" ${ }^{2}$ for the sake of status.

For women, we can arguably support that marriage was a key step towards their legal independence, as through marriage they became mothers and by fulfilling their reproductive role were granted rights and respect by virtue of motherhood. ${ }^{3}$

Papyrological data suggest that women stated that acted without a kv́pıs up to the $7^{\text {th }}$ century, the last such papyrus is dated 570 A.D ....ca.?- $\left.\chi \omega\right]$ pis кupíov10[ -ca.?-

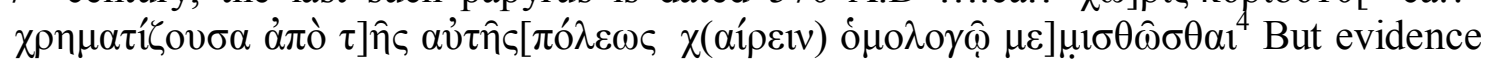
and researchers agree that in late antique Egypt only widows acted without a guardian, and when guardians appear, they are the husbands. ${ }^{5}$

But as these applied to legal tutelage and women's legal freedom, a distinction between the private and social freedom of women should be made; women seem to have had a set of obligations and rights within the household, although the power of the mother was not legally established in Roman law. ${ }^{6}$

To sum up, from 212 A.D onwards and by the $3^{\text {rd }}$ century guardianship of women had been diminished. ${ }^{7}$ This should be attributed to the fact that all Roman women could could take advantage of the ius trium liberorum, ${ }^{8}$ up until its abolition in $534 \mathrm{CE}$ by Emperor Justinian. ${ }^{9}$

In the meantime, the reign of Constantine (306 - 337 AD) "re-instituted" terms and traditions of guardianship and revised the legal framework of marital law ${ }^{10}$, most

\footnotetext{
1 J. Sheridan, "Women without guardians: An updated list" The Bulletin of the American Society of Papyrologists 33, No. 1/4. (1996): $117-131$.

2 Bowman, Egypt after the Pharaohs, 159.

3 Andrew T. Bierkan, Charles P. Sherman and Emile Stocquart, Jur., "Source: Marriage in Roman Law", The Yale Law Journal 16, No. 5 (Mar., 1907), 311.

${ }^{4}$ Sheridan, "Women without guardians...between the 5th to 7th century 43 papyri mention "without kyrios"...cf. SB I 5271, cf. Anal Pap. 23.24 .169 (584-585 CE), cf. BGU. 196 (Arsinoite; 250-300 CE),

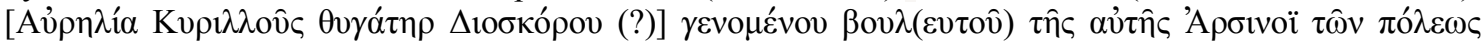

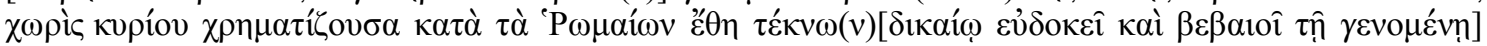

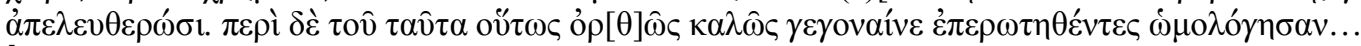

5 Harper, Marriage and Family, 10

${ }^{6}$ B. Rawson, A Companion to Families in the Greek and Roman worlds (Chichester, West Sussex, U.K.: Wiley-Blackwel, 2013),121.

${ }^{7}$ Vuolanto, Women and property, 208.

${ }^{8}$ Vandorpe \& Waebens, "Women and Gender in Roman Egypt", 420.

${ }^{9}$ J. B. Moyle, The Institutes of Justinian, Trans. by John Baron Moyle, 5th ed., (Oxford: Clarendon Press, 1913), TIT. 9 In potestate nostra sunt liberi nostri, quos ex iustis nuptiis procreaverimus. 1. Nuptiae autem sive matrimonium est viri et mulieris coniunctio, individuam consuetudinem vitae continens. 2. Ius autem potestatis, quod in liberos habemus, proprium est civium Romanorum: nulli enim alii sunt homines qui talem in liberos habeant potestatem qualem nos habemus. 3 Qui igitur ex te et uxore tua nascitur, in tua potestate est: item qui ex filio tuo et uxore eius nascitur, id est nepos tuus et neptis, aeque in tua sunt potestate, et pronepos et proneptis et deinceps ceteri. qui tamen ex filia tua nascitur, in tua potestate non est, sed in patris eius.

10 J. Grubbs, "Abduction Marriage in Antiquity: A Law of Constantine (CTh IX. 24. I) and its Social Context," The Journal of Roman Studies, 79 (1989): 66.
} 
importantly that "the minor wife" was under her husband's guardianship, and agnatic guardianship. ${ }^{1}$

The legal provisions preserved in the Constantine, Theodosian, and Justinian Codes are an invaluable source of information for the history of women in the postclassical period of Roman law. ${ }^{2}$ Byzantine rule of Egypt in $324 \mathrm{AD}$ had as a result seen the introduction of a debatable Christian galvanized legislation, ${ }^{3}$ but tutelage as practiced in in the Roman period was never reinstituted.

The last time a legal source mentioned guardianship of women was in 293,4 and from the $4^{\text {th }}$ to the $6^{\text {th }}$ centuries there are only four cases of women who act with a guardian. In all four cases the guardians were their husbands. On the other hand, during the same period, there are about sixty cases of women who act without a guardian citing the ius leberoum and the last reference is in $389 .^{5}$ Papyri clearly reveal that widows could perform legal activities without a guardian.

By the end of Late Antiquity in Egypt the legal guardianship had disappeared. There are no legal documents which confirm the legal provision for a guardian, but husbands would be needed to be present or give their consent if family property was at stake. To this we should add psychological, cultural, and social trends and patterns which would put men or women in the frame of legal transactions, who would act as synestos,

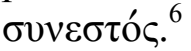

In a papyrus of $3^{\text {rd }} \mathrm{CE}$, a free woman accompanied by her husband according to the

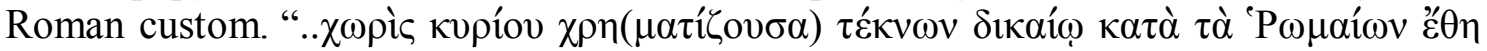

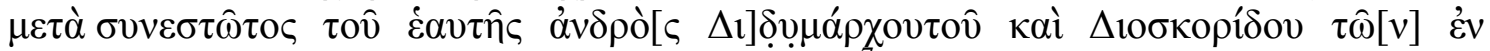
$\Lambda$

\footnotetext{
${ }^{1}$ A. Arjava, Women and Law, 117 - 178; cf. Scott. The civil law, T 30, 3 The Lex Claudia having been abrogated by a Constitution of the Emperor Constantine, of Divine Memory, and the right of agnation remaining unimpaired by virtue of the authority of the ancient law, the blood-relatives, that is to say, the brother, as well as the paternal uncle and the other kindred legally authorized, are called to the guardianship of females.

${ }^{2}$ Harper, Marriage and Family, 2161

3 Jane Rowlandson, Women and society in Greek and Roman Egypt: a sourcebook (Cambridge: Cambridge University Press, 1998), 155 - 156; Vandorpe, \& Waebens, "Women and Gender in Roman Egypt, 416-417, 420... "For the Roman administration the culturally mixed population of GrecoEgyptian inhabitants of the countryside or chora were all considered Egyptian, peregrini Aegyptii or Aigyptioi and chosen to retain only the Greek administration on all levels." 44; cf. women dealing with their own inheritance BGU I 189 (Arsinoite; 7 CE), SB I 5243 (Arsinoite; 7 CE), SB I 5245 (Soknopaiou Nesos; 15 CE).

${ }^{4}$ Grubbs, Women and the Law, 44; Cf. Rawson, A Companion to Families, 120 ...Whereas guardianship of women weakened over time, guardianship of children was strengthened and extended. The latter institution received far more attention from the classical jurists than the former. As a result, guardianship of children was a pervasive institution with highly developed rules about care of the child's property and possibly had widespread economic consequences in as much as it strongly encouraged conservative investment by guardians so as to protect the value of the estate...

${ }^{5}$ J. Beaucamp, Le statut de la femme a Byzance. II. Les pratiques sociales (Paris: 1992), 193 -267.

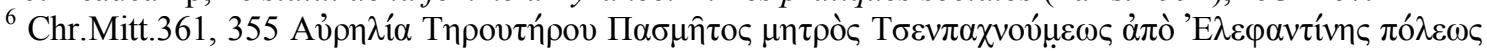

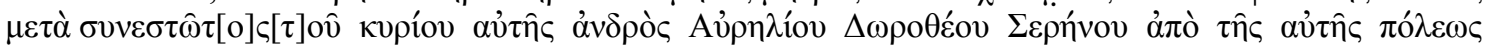

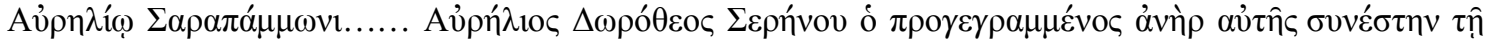

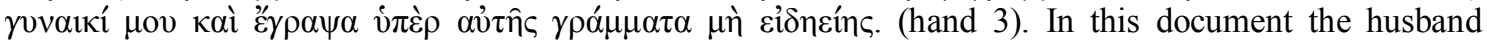
accompanies his wife in administrative services because she is illiterate.

${ }^{7}$ P.Berl. Moller.1 (Herm<Lykopolite; 300 CE).
} 


\section{Conclusion:}

The legal diversity in Egypt and the vague perception of Roman guardianship by the local population had as a result the gradual disappearance of the institution of guardianship of adult women in Egypt as well as in the eastern parts of the Empire.

When there was not any legal necessity for the guardian's presence, social and traditional norms as well as psychological factors led some women to seek the assistance or presence of a guardian.

Papyrological analysis suggests that women had increased legal independence after the $4^{\text {th }}$ century and up until the end of Antiquity in Egypt. In the few cases a кúpioc appears in the documents, it is always the husband which clearly indicates that Roman tutela mulierum had lost its appeal.

However, to understand better the legal environment for women, we should mention that laws from the $4^{\text {th }}$ century and onwards provisioned a different approach towards women and men. ${ }^{1}$ Different legal provisions for men and women, different attitudes towards gender were real, expected and accepted.

History should be analyzed in tempore, and modern concepts of equality or independence would offer a biased conclusion which would finally deprive us from understanding the late Antique Egypt. When evidence reveals that women could perform legal and business transactions with guardians, we should interpret it as assistance and not necessarily as superintendence. Finally, women were undoubtedly less privileged legally and the socio-economic structure had men at its basis, but this did not deprive them of being active members within the household and present in the social sphere. But towards the end of Antiquity Imperial legislation moved from men's single authority to privilege the family, thus we see women more active within the household and being granted rights over children's guardianship and patrimonial estate. Finally, motherhood and widowhood were the ways women managed to escape guardianship and achieve legal independence.

\footnotetext{
${ }^{1}$ Grubbs, Women and the Law, 52
} 


\section{Bibliography}

\section{Papyri Collections:}

- AnalPap= Analecta Papyrologica 23 - 24 (2011-2012), 168-170 (2011-2012 [2013])BASP = Bulletin of the American Society of Papyrologists: Supplements. Published irregularly by the Society, 1973- .

- BGU = Aegyptische Urkunden aus den Königlichen (laterStaatlichen) Museen zu Berlin, Griechische Urkunden. Berlin. II, 1898. Nos. 362-696

- Chrest. Mitt. = L. Mitteis and U. Wilcken, Grundzüge und Chrestomathie der Papyruskunde, II Bd. Juristischer Teil, II Hälfte Chrestomathie. Leipzig-Berlin 1912. Nos. 1-500. [MF 2.122 - 123 (with Grundzüge); rp. GO, all 4 vols.]

- CPR = Corpus Papyrorum Raineri. Vienna. V, Griechische Texte II, ed. J.R. Rea and P.J. Sijpesteijn. 1976. Nos. 1-25 plus P.Vindob. G 39847 (No. 26).

P. Aberd $=$ Catalogue of Greek and Latin Papyri and Ostraca in the Possession of the University of Aberdeen, ed. E.G. Turner. Aberdeen 1939. (Aberdeen Univ. Studies 116). Nos. 1 - 2, 7-72, 104-197 are papyri; nos. 3-6, 73-103 ostraca. [MF 2.104]

- P. Abinn: The Abinnaeus Archive: Papers of a Roman Officer in the Reign of Constantius II, ed. H.I. Bell, V. Martin, E.G. Turner, D. van Berchem. Oxford 1962. Nos. 1-82. [Rp. CG]. See also SB X 10755, SB XIV 11380 and SB XX 14954. p.abinn

- P.Cair.Isid. = The Archive of Aurelius Isidorus in the Egyptian Museum, Cairo, and the University of Michigan, ed. A.E.R. Boak and H.C. Youtie. Ann Arbor 1960. Nos. 1-146. [MF 1.28] p.cair.isid

- P.Cair.Masp. = Papyrus grecs d'époque byzantine, Catalogue général des antiquités égyptiennes du Musée du Caire, ed. J. Maspero. Cairo. p.cair.masp

I, 1911. (Cat. 51). Nos. 67001-67124. [MF 1.38; rp. OZ/CG] p.cair.masp;1 Online: archive.org

- P. Hamb = Griechische Papyrusurkunden der Hamburger Staats- und Universitätsbibliothek. III, ed. B. Kramer and D. Hagedorn. Bonn 1984. (Pap.Texte Abh. XXXI). Nos. 193-234.

IV, Milan 1967. Nos. 204-257, plus 3 Coptic texts. p.mil.vogl;4

- P. Herm= Papyri from Hermopolis and Other Documents of the Byzantine Period, ed. B.R. Rees. London 1964. (Egypt Exploration Society, Graeco-Roman Memoirs 42). Nos. 1-85. [EES] p.herm

- P. Oxy.= The Oxyrhynchus Papyri. Published by the Egypt Exploration Society in Graeco-Roman Memoirs. London. The number in parentheses at the end of each entry is the number in this series. Earlier vols. carry the heading of Egypt Exploration Fund, Graeco-Roman Branch; even after the title change numbers were not assigned to the volumes until the 1950s. The system followed here is that adopted retroactively by the EES. [all vols. EES], XXII, Nos. 2309-2353, ed. E. Lobel and C.H. Roberts. 1954. (31)

I, Nos. 1-207, ed. B.P. Grenfell and A.S. Hunt. 1898. (1) p.oxy;1 Cf. P.Oxy.Descr. Online: archive.org Cf. P.Oxy.Descr. 
XII, Nos. 1405-1593, ed. B.P. Grenfell and A.S. Hunt, 1916. (15) p.oxy; 12 Online: archive.org

- SB = Sammelbuch griechischer Urkunden aus Aegypten. (A collection of documentary papyri, ostraca, inscriptions, mummy tablets and related texts published in journals or unindexed catalogues. Begun by F. Preisigke in 1915, continued by F. Bilabel, E. Kiessling, and H.-A. Rupprecht). In progress.

I, Strassburg and Berlin 1913-1915. Nos. 1-6000. [MF 1.33; rp. WdG] Online: archive.org

III, Berlin and Leipzig 1926—1927. Nos. 6001—7269. [MF 1.35; rp. WdG]

\section{References:}

- Alonso, J. L., "The status of peregrine law in Egypt", Journal of Juristic Papyrology 43 (2013): 351-404.

- Andrew T. Bierkan, Charles P. Sherman and Emile Stocquart, Jur., "Source: Marriage in Roman Law", The Yale Law Journal, Vol. 16, No. 5 (Mar., 1907).

- Arjava, A., The guardianship of women in Roman Egypt in Kramer, B. e.a. eds., Akten des 21. Internationalen Papyrologenkongresses, Berlin 13-19. 8.1995 Vol. 1, APF Beihefte 3. Stuttgart: Teubner 1997.

- Arjava, A., Women and Law in Late Antiquity. Oxford: Oxford University Press, 1996.

- Borkowski, J. A., Plessis, Du P., Borkowski's textbook on Roman law. New York: Oxford University Press, 2020.

- Bowman, Alan k., Egypt after the Pharaohs: 332 B.C. - AD 642 from Alexander to the Arab Conquest. USA: University of California Press, 1990.

- Caldwell, L., The Female Transition to Adulthood in the Early Roman Empire. Published PhD diss., University of Michigan, 2004.

- Clark, G., Women in late antiquity: Pagan and Christian life-styles. Oxford: Oxford University Press, 2008.

- Cooper, K., and Wood, J., Social Control in Late Antiquity: the violence of small worlds. Cambridge: Cambridge University Press, 2021.

- Esler, Philip, Modeling Early Christianity: Social-Scientific Studies of the New Testament in its context. London: Routledge, 1995.

- Gardner, J., Women in Roman Law \& Society. Bloomington and Indianapolis: Indiana University Press, 1986.

- Grubbs, J., "Abduction Marriage in Antiquity: A Law of Constantine (CTh IX. 24. I) and its Social Context," The Journal of Roman Studies, 79 (1989): 59-83

- Grubbs, J., Women and the Law in the Roman Empire. A sourcebook on marriage, divorce and widowhood. London and New York: Routledge, 2002.

- Harper, K., Marriage and Family in late antiquity in S. F. Johnson, Oxford Handbook of Late Antiquity. Oxford, New York: Oxford University Press, 2012 (prepublication copy).

- Johnson, S. F., The Oxford Handbook of Late Antiquity. Oxford, New York: Oxford University Press, 2012.

- Keenan, J., Manning, \& U. Yiftach-Firanko, Law and Legal Practice in Egypt from Alexander to the Arab Conquest. A Selection of Papyrological Sources in 
Translation, with Introductions and Commentary. Cambridge: Cambridge University Press, 2014

- Mathisen, R., Law, Society, and Authority in Late Antiquity. Oxford: Oxford University Press, 2019.

- Mirkovic, M. "Patria Rotestas or Murder in the Family", Annals FLB-Belgrade Law Review, Year LXIII, No 3, Anali Pravnog fakulteta u Beogradu, 63 (3) (2015): 5-17.

- Moyle, J. B., The Institutes of Justinian, Trans. by John Baron Moyle, 5th ed., Oxford: Clarendon Press, 1913.

- Mueller, I., "Lower-class widows and their social relationships: A comparative study of Roman tombstone inscriptions and papyri from Roman Egypt". In Le rôle et le statut de la femme en Égypte hellénistique, romaine et Byzantine, Studia Hellenistica 37, ed. Henri Melaerts and Leon Mooren (2002): 265 - 281

- Nifosi, A., Becoming a woman and mother in Greco-Roman Egypt: women's bodies, society and domestic space. London, New York: Routledge, Taylor et Francis Group, 2019).

- Rawson, B., A companion to families in the Greek and Roman worlds. Chichester, West Sussex, U.K., USA: Wiley-Blackwel, 2013.

- Rowlandson, Jane, Women and society in Greek and Roman Egypt : a sourcebook (Cambridge: Cambridge University Press, 1998

- Rowlandson, J. and Bagnall, R., Women and society in Greek and Roman Egypt: a sourcebook. Cambridge, U.K: Cambridge University Press, 2009.

- Saller, R., Patriarchy, property and death in the Roman Family. Cambridge: Cambridge University Press, 2009.

- Sheridan, J., "Women without guardians: An updated list" The Bulletin of the American Society of Papyrologists. Vol. 33, No. 1/4, (1996).

- Skalec, Aneta, "Men and women as neighbors in Ptolemaic and Roman Egypt (331 BC - 641 AD)": In (Wo)Men in Legal History. Centre d' Histoire Judiciaire. Poland: University of Warsaw, 2016.

- Taubenschlag, R., The law of Greco-Roman Egypt in the light of the papyri, 332 B.C. - 640 AD.Warszawa: Panstwowe Wydawnictwo Naukowe, 1955.

- Vandorpe, K., \& Waebens, S., "Women and Gender in Roman Egypt: The Impact of Roman Rule in Tradition and Transformation: Egypt under Roman Rule". Proceeding of the International Conference, Hildesheim, Roemer - and Pelizaeus Museum, 3-6 July 2008. Leiden - Boston: Brill, 2010.

- Vuolanto, V., Women and the Property of Fatherless Children in the Roman Empire. In Women, Wealth and Power in the Roman Empire, Setala, P. et. al. Vol. 25. Rome: Acta Instituti Romani Finlandiae, 2002. 